\title{
ANTIBACTERIA ACTIVITY OF GASTROPOD ASSOCIATION BACTERIA FROM MANGROVE ECOSYSTEM AGAINST BACILLUS CEREUS AND ESCHERICHIA COLI AND IT'S POTENCY OF APPLICATION FOR BELANAK FISH (MUGIL SUBVIRIDIS)
}

\author{
Patria Ami Wijaya $^{a} *$, Delianis Pringgenies ${ }^{b}$, Ervia Yudiati $^{\text {b }}$ \\ ${ }^{a}$ Marine Science Study Program, Diponegoro University, Semarang, Indonesia, \\ bepartment of Marine Science, Diponegoro University, Semarang, Indonesia \\ *Koresponden penulis : wpatriaami@gmail.com
}

\begin{abstract}
Abstrak
Bakteri asosiasi gastropoda dari ekosistem mangrove memiliki potensi sebagai antibakteri yang dapat dimanfaatkan dalam produk perikanan. Kontaminasi Bacillus cereus dan Escherichia coli dapat menyebabkan pembusukkan pada daging ikan. Penelitian ini bertujuan untuk mengidentifikasi bakteri asosiasi yang dapat menghambat $B$. cereus dan $E$. coli, serta potensinya dalam menghambat bakteri kontaminan pada daging ikan Belanak (Mugil subviridis). Pengambilan sampel di Mangrove Education Park, Kecamatan Tugu, Semarang. Uji antibakteri dilakukan di Laboratorium Tropical Marine Biotechnology, Universitas Diponegoro. Prosedur penelitian adalah isolasi bakteri, uji antibakteri, identifikasi secara biokimia, dan uji aplikasi potensi terhadap ikan Belanak. Gastropoda yang didapat adalah Certhideopsilla alata, Cerithidea quoyii, Cassidula aurisfelis, Cassidula nucleus, dan Telescopium telescopium. Hasil isolasi bakteri sebanyak 61 isolat. Kultur yang paling menghambat pertumbuhan patogen adalah GMT 3.2.5 dan GMT 4.1.3 (8,48 mm dan 7,84 mm). Karakterisasi menunjukkan GMT 3.2.5 dan GMT 4.1.3 lebih dekat pada genus Micrococcus sp. dan Bacillus sp. Supernatan GMT 3.2.5 dan GMT 4.1.3 dapat menghambat bakteri kontaminan ikan Belanak dengan jumlah koloni $1150 \mathrm{x}$ $10^{3}$ dan $265 \times 10^{3} \mathrm{CFU} / \mathrm{ml}$. Jumlah koloni lebih sedikit dibanding tanpa perendaman yaitu $2312 \times 10^{3} \mathrm{CFU} / \mathrm{ml}$.
\end{abstract}

Kata kunci: Bakteri Asosiasi Gastropoda, Aktivitas Antibakteri, Pembusukan Ikan

\begin{abstract}
Gastropod association bacteria from mangrove ecosystem have a great potency as antibacterial. The contamination of Escherichia coli and Bacillus cereus cause damage in fish product. The aims of this research are to identify gastropod association bacteria that can inhibit $E$. coli and B. cereus growth, as well as the contamination bacteria in Belanak (Mugil subviridis). Gastropods sample Certhideopsilla alata, Cerithidea quoyii, Cassidula aurisfelis, Cassidula nucleus, Telescopium telescopium were collected at Mangrove Education Park, Tugu, Semarang. The research procedure was isolation, antibacteria test, biochemical identification, and the potency to inhibit contaminant bacteria in Belanak fish (Mugil subviridis). There were 61 bacteria isolated. Thirteen isolates were able to inhibit E. coli and eight to B. cereus. Supernatant of GMT 3.2.5 and GMT 4.1.3 have the most widely inhibition zone, (8,48 $\mathrm{mm}$ and 7,84 $\mathrm{mm})$. Biochemistry identification shown that GMT 3.2.5 and GMT 4.1.3 has identic characteristic with genus Micrococcus sp. and Bacillus sp. Total plate count (cfu/ml) of bacteria from Belanak fish flesh that soaked by Micrococcus sp. GMT 3.2.5 and Bacillus sp. GMT 4.1.3 supernatant were $115 \times 10^{4}$ and $265 \times 10^{3}$ colony. The colony were less than negative control ( $2312 \times 10^{3}$ colony). The association bacteria can inhibit contaminant bacteria in Belanak fish.
\end{abstract}

Keywords: Gastropod Association Bacteria; Antibacterial Activity; Fish Decomposition

\section{INTRODUCION}

Gastropod association bacteria have great potency for antibacterial activity. The previous study showed that the association bacteria from gastropods Conus miles, Stramonita armigera, and Cymbiola vespertillo can inhibit Multi Drug Resistant bacteria growth [1]. Association bacteria synthesized the antibacterial compound from 
its host [2]. Gastropod were one of the important sources to produce bioactive compound that have antibacterial activity [3]. Antibacterial is important compounds of the host defence system of many animal species [4].

Bacillus cereus and Escherichia coli are bacteria that live in any condition and environment. Bacillus cereus and Escherichia coli could contaminate fish product. Bacillus cereus and Escherichia coli cause rapid deterioration and decomposition of fish products. These contaminant bacteria degrade protein from the fish for its metabolism [5]. Contamination occurred during fish processed, there were from the unhygienic environment, device, or workers [6]. Contaminated fish consumed by humans can cause poisoning in humans.

The aims of this research are to determine gastropod association bacteria that can inhibit $E$. coli and B. cereus growth, knowing genus of active bacteria, and growth inhibition against contamination bacteria in Belanak Mugil subviridis. Total count of contaminant bacteria in Belanak fish will illustrate the potency of gastropod association bacteria.

\section{MATERIALS AND METHODS}

The research was conducted in February-July 2018 at Tropical Marine Biotechnology, Marine Science and Oceanography Laboratory, Diponegoro University, Semarang, Indonesia. The procedure of research was sample preparation, association bacteria isolation, antibacterial test, biochemical identification, and potency to inhibit bacterial contamination in Belanak fish Mugil subviridis.

\section{Sample Preparation}

Five different species of Gastropods samples were collected at Mangrove Education Park, Tugu, Semarang. Sampling was done by purposive sampling methods. Gastropods were handed in directly by picking hand methods. The samples were collected in sterile Ziplock plastic and then put it on the cool box. Gastropods sample were brought in to laboratory for association bacteria isolation and followed by antibacterial test.

\section{Association Bacteria Isolation}

Gastropod association bacteria were isolated by some serial dilution. One gram of gastropods inner tissue was diluted at $9 \mathrm{ml}$ sterile sea water. Some serial was administered at $10^{-1}-10^{-5}$. Serial dilution at $10^{-3}, 10^{-4}, 10^{-5}$ were cultivated in 2216 Zobell agar, incubated for 3 days at $37^{\circ} \mathrm{C}$, and then isolated to get the single pure culture. Purified gastropod association bacteria were kept at slant Nutrient Agar and incubated for 2 days at $37^{0} \mathrm{C}$.

\section{Antibacterial Test}

The bioactivity of purified association bacteria was screened by overlay methods against Bacillus cereus and Escherichia coli [7]. Association bacteria were cultured by dotting in 2216 Zobell agar, and then incubated for 2 days at $37^{\circ} \mathrm{C}$. In the first day of incubation, Bacillus cereus and Escherichia coli were cultivated in $5 \mathrm{ml}$ Nutrient Broth, and then shakes at $120 \mathrm{rpm}$ for 24 hours. Bacillus cereus and Escherichia coli (1\% total volume of Soft Agar) were cultivated in warm Soft Agar Zobell, and then pour it on to association bacteria culture in 2216 Zobell Agar, incubated for $1-2$ days at $37^{\circ} \mathrm{C}$. Active association bacteria were cultured at $10 \mathrm{ml}$ Nutrient Agar and shaken for 5 days at 120 rpm. The 5 days culture were then centrifugated at $3000 \mathrm{rpm}$. Antibacterial assay was done by Kirby-Bauer or Paper Disk

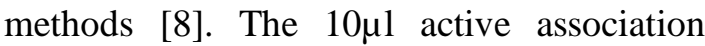
bacteria supernatant were taken and then pour it on to $6 \mathrm{~mm}$ paper disk. Prior to this, 2216 Zobell Agar were cultured by pathogenic bacteria. This was then followed by incubation for 1 and 2 days at $37^{\circ} \mathrm{C}$.

\section{Biochemical Identification}

Identification of active association bacteria was done by biochemical methods. Biochemical identification based on Bergeys Manual of Determinative Bacteriology $9^{\text {th }}$ edition [9]. Serial biochemical tests including gram staining, catalase test, oxidase test, nitrate reduction test, sulphides hydrogen test, 
MR test, VP test, urea hydrolysis test, starch hydrolysis test [10], sugar fermentation test, tryptophan hydrolysis test [11], and gelatine hydrolysis [12], were done.

\section{Application Test in Belanak fish Mugil subviridis}

Application test of active bacteria supernatant was done by soaking 200-gram flesh of Belanak fish for 5 hours on the active bacteria supernatant. We used Belanak fish without any soaking of supernatant as negative control. Contaminant bacteria was counted by Total Plate Count method. One gram of soaked coded Belanak fish were isolated by some serial dilution and then cultivate by spread plate methods in 2216 Zobell Agar. Contamination bacteria were counted and compared to the negative control.
Contaminant bacteria were accounted by this formula below:

$\mathrm{CFU} / \mathrm{ml}=$ Mean of total bacteria $\times(1 /$ Dilution factor)

\section{RESULT AND DISCUSSION}

Gastropods sample Certhideopsilla alata, Cerithidea quoyii, Cassidula aurisfelis, Cassidula nucleus, Telescopium telescopium were collected at Mangrove Education Park, Tugu, Semarang. There were 61 bacteria managed to isolate from those five species of Gastropods. Thirteen isolates were able to inhibit $E$. coli and eight to B. cereus. As seen in Table 1, supernatant of GMT 3.2.5 and GMT 4.1.3 have the most widely inhibition zone $(8,48 \mathrm{~mm}$ and $7,84 \mathrm{~mm})$

Table 1. The Result of Antibacterial Test Gastropods Association Bacteria

\begin{tabular}{|c|c|c|c|c|}
\hline \multirow{3}{*}{ Bacteria Code } & \multicolumn{4}{|c|}{ Inhibition Zone (mm) } \\
\hline & \multicolumn{2}{|c|}{ E. coli } & \multicolumn{2}{|c|}{ B. cereus } \\
\hline & 24 hours & 48 hours & 24 hours & 48 hours \\
\hline GMT 4.1.3 & $5.125 \pm 0.95$ & $7.845 \pm 2.0$ & 0 & 0 \\
\hline GMT 4.1.5 & $3.95 \pm 1.48$ & $5.765 \pm 2.07$ & $3.38 \pm 0.25$ & 0 \\
\hline GMT 5.2.6 & $5.15 \pm 0.63$ & $4.68 \pm 0.67$ & $5.065 \pm 1.32$ & $3.1 \pm 0.28$ \\
\hline GMT 3.2.5 & $4.65 \pm 0.07$ & $8.48 \pm 0.77$ & $3.48 \pm 0.16$ & $5.68 \pm 0.91$ \\
\hline GMT 5.1.2 & $4.18 \pm 0.82$ & $5.215 \pm 1.29$ & 0 & 0 \\
\hline GMT 5.1.3 & $4.03 \pm 0.8$ & $5.465 \pm 0.47$ & 0 & 0 \\
\hline GMT 2.2.9 & $3.75 \pm 0.49$ & 0 & 0 & 0 \\
\hline GMT 4.2.7 & 0 & 0 & 0 & 0 \\
\hline GMT 4.1.2 & $2.765 \pm 0.33$ & 0 & $2.7 \pm 0.7$ & $3.845 \pm 1.67$ \\
\hline GMT 4.1.1 & $2.7 \pm 0.56$ & 0 & 0 & 0 \\
\hline GMT 3.2.3 & 0 & 0 & 0 & 0 \\
\hline GMT 3.2.1 & $3.2 \pm 0.98$ & 0 & 0 & 0 \\
\hline GMT 5.1.4 & $3.815 \pm 0.58$ & 0 & 0 & 0 \\
\hline GMT 5.1.1 & $4.4 \pm 0$ & $5.85 \pm 0.35$ & $3.565 \pm 0.65$ & $4.04 \pm 1.4$ \\
\hline GMT 2.3.12 & $3.98 \pm 0.25$ & 0 & 0 & 0 \\
\hline GMT 5.2.5 & $3.065 \pm 0.47$ & 0 & 0 & 0 \\
\hline GMT 4.1.4 & $3.9 \pm 0.14$ & 0 & 0 & 0 \\
\hline GMT 2.5.14 & 0 & 0 & 0 & 0 \\
\hline Amoxicilin & $23.75 \pm 0.21$ & $23.93 \pm 0.18$ & $7.405 \pm 0.07$ & $6.6 \pm 0.28$ \\
\hline Sterile NB & 0 & 0 & 0 & 0 \\
\hline
\end{tabular}

Footnote: Bold font: The most potential culture

The biochemical identification shown that GMT 3.2.5 has an identical characteristic to genus Micrococcus sp. and GMT 4.1.3 to genus Bacillus sp. Total plate count (cfu/ml) 
of bacteria from Belanak fish flesh that soaked by Micrococcus sp. GMT 3.2.5 and Bacillus sp. GMT 4.1.3 supernatant were $1150 \times 10^{3}$ and $265 \times 10^{3}$ colony (Table 2). It has proven, that the colony were less than the negative control ( $2312 \times 10^{3}$ colony).

Table 2. Total Plate Count of Contaminant Bacteria in Belanak fish

\begin{tabular}{ccc}
\hline Num. & Supernatant Code & $\begin{array}{c}\text { Bacteria Colony } \\
\text { Total (CFU) }\end{array}$ \\
\hline 1. & GMT 4.1.3 & $265 \times 10^{3}$ \\
2. & GMT 3.2.5 & $1150 \times 10^{3}$ \\
3. & Negative Control & $2312 \times 10^{3}$ \\
\hline
\end{tabular}

Identified gastropods were Cerithideopsilla alata, Cerithidea quoyii, Cassidula aurisfelis, Cassidula nucleus, and Telescopium telescopium. Identification was done based on Identification Book [13]. Cerithideopsilla alata is a member of Potamididae family, shell length $2,5 \mathrm{~cm}$, blackish brown color, and pointed apical whorl. The habitat of gastropod was in coastal, estuary, and mangrove ecosystem [14]. Secondly species, Cerithidea quoyii is Potamididae family. Cerithidea quoyii has shell length $3,5 \mathrm{~cm}$, yellowish brown color, spiral cone shell, convex body whorl, and blunt apical whorl. Gastropod C. quoyii which live in root in root and stem of mangrove [15]. C. aurisfelis is a member of Potamididae family. Gastropod Cassidula aurisfelis has shell length $2,5 \mathrm{~cm}$, dark brown color with yellow line, convex body whorl, and tight aperture. The $C$. aurisfelis shell has a unique right spiral pattern. Their habitat is in mud substrate in mangrove ecosystem. Gastropod Cassidula nucleus was lived in mud substrate in mangrove ecosystem, Ellobidae family, 2 $\mathrm{cm}$ in shell length, brown color with spiral line, convex body whorl, pointed apical whorl, and tight aperture. C. nucleus lives in mangrove substrate [14]. The last species is Telescopium telescopium. Potamididae family, has $7 \mathrm{~cm}$ in shell length, blackish brown colour, spiral pattern. This gastropod has bold and hard shell, widen aperture, and pointed apical whorl. T. telescopium live in brackish water and mud substrate in mangrove ecosystem [16].

We succeed to isolate 61 association bacteria and 21 of those were active. 13 bacteria were able to inhibit pathogen bacteria. Antibacterial experiments were done by agar diffusion (modified Kirby-Bauer). Inhibition zone of GMT 4.1.3 to E. coli were $7,48 \mathrm{~mm}$. In other hand, GMT 3.2.5 was succeeded to suppress the E. coli growth in $8,48 \mathrm{~mm}$ inhibition zone. Even though, the Amoxicillin inhibition zone was greater (23 $\mathrm{mm}$ ), GMT 3.2.5 has a potency to reduce the contaminate bacteria such as $E$. coli. As we were only centrifuge the bacteria culture, there will be much more information can be explored to find the more powerful compounds and several methods on extraction [17].

The performance of inhibition zone shows that gastropod association bacteria produce antibacterial compound. There are several steps on antibacterial mechanism. Firstly, those bacteria were inhibit synthesizing the pathogen bacteria cell wall, increasing cell membrane permeability, and finally, irritate cell protein synthesize [18].

The supernatant of GMT 3.2.5 and GMT 4.1.3 were inhibiting E. coli greater, rather than B. cereus. Our postulate is, E. coli is negative gram bacteria and have a thinner cell wall compare to positive gram bacteria such as B. cereus. Negative gram bacteria cell wall contains $10 \%$ peptidoglycan, lipopolysaccharide, and $11-22 \%$ lipid. Antibacterial compound of association bacteria can easily damage the cell wall of $E$. coli and inhibit $E$. coli growth, rather than $B$. cereus. Reported that $B$. cereus cell wall contain of $60-100 \%$ peptidoglycan, and $1-$ $4 \%$ lipid [19]. The function of cell wall is in relation with the protection of bacteria osmotic pressure. Cell wall is also having a role in cell fission [20].

Inhibition zone that created by GMT 3.2.5 and GMT 4.1.3 were not clear but there some colony of pathogen inside. This is an indication that GMT 3.2.5 and GMT 4.1.3 are bacteriostatic. The bacteriostatic mechanism is to inhibit protein synthesis from pathogenic bacteria, it binds to the ribosome of the bacteria. The bonding was temporary and not strong enough, so ribosome will be released again when antibacterial compound concentration was decreased. So, therefor, the bacteria will grow up again [21]. Antibacterial strength, indicated by inhibition zone, were divided in to four groups, there were very strong $(\geq 20 \mathrm{~mm})$, strong $(10-20 \mathrm{~mm})$, intermediate $(5-10 \mathrm{~mm})$, and weak $(\leq 5 \mathrm{~mm})$ 
[22]. Bacteria GMT 3.2.5 and GMT 4.1.3 were in intermediate antibacterial strength zone.

Biochemistry identification shown that the GMT 3.2.5 and GMT 4.1.3 have an identic characteristic with genus Micrococcus sp. and Bacillus sp. (Table 3). Bacteria genus Micrococcus sp. was positive gram bacteria, coccus, irregular position, and lived-in land or water. Micrococcus sp. has $\pm 0,5-2,5 \mu \mathrm{m}$ cell size [23]. Micrococcus sp. was organic decomposer bacteria. It can decompose organic material in euphotic area. Bacillus sp. is a positive gram bacterium, bacillus, obligate aerobe, and can be found in any environment. Bacillus sp. can produce endospore when the environment was not in good condition [24]. Bacillus sp. is an organic decomposer bacterium [25].

Table 3. Biochemistry Identification

\begin{tabular}{lcc}
\hline \multicolumn{1}{c}{ Test } & GMT 3.2.5 & GMT 4.1.3 \\
\hline Catalase & + & + \\
Oxidase & + & + \\
Fermentation: & & \\
$\quad$ Glucose & - & A \\
Xylose & - & - \\
$\quad$ Lactose & - & - \\
$\quad$ Mannitol & - & A \\
Hydrolysis: & & \\
$\quad$ Gelatine & + & + \\
$\quad$ Starch & - & - \\
$\quad$ Urea & - & + \\
Tryptophan & - & - \\
Nitrate & - & + \\
Reduction & - & + \\
H 2 Product & - & - \\
MR & - & - \\
VP & + & \\
\hline
\end{tabular}

Footnote:

$(+)=$ Positive test result

$(-)=$ Negative test result

Total plate count shown that GMT 3.2.5 and GMT 4.1.3 can inhibit contaminant bacteria in Belanak fish. Total contaminant bacteria in Belanak fish soaked by association bacteria supernatant were less than negative control. This indicated that inhibition occurred during soaking process [26]. This research positively suggest that GMT 3.2.5 and GMT 4.1.3 have antibacterial compound against contaminant bacteria in Belanak fish. In conclusion, GMT 3.2.5 and GMT 4.1.3 have some potency as natural material for preservative in fish product. Moreover, some more research need to be done to optimize this potency.

\section{CONCLUSION}

Association bacteria of gastropod GMT 3.2.5 and GMT 4.1.3 were able to inhibit $E$. coli and B. cereus. Biochemistry identification shown that GMT 3.2.5 has identic characteristic with genus Micrococcus sp. and GMT 4.1.3 has identic characteristic with genus Bacillus sp. The supernatant from these bacteria can inhibit contaminant bacteria in Belanak fish (M. Subviridis) based on Total Plate Count result.

\section{ACKNOWLEDGEMENTS}

We would like to thank Department of Marine Science that had support all laboratory instrumental in the research. Many thanks to Sakti Imam Muchlissin and Muhammad Syaifudien Bahry for their kind assistance in the research.

\section{REFERENCES}

[1] Pringgenies, Delianis. 2015. Isolation of Mollusc Simbion Bacteria Produces Antibacteria Compounds Against Multi Drug Resistant (MDR). Research of Fisheries and Marine. Diponegoro University.

[2] Burgess, J. G., K. G. Boyda, E. Amstronga, Z. Jianga, L. Yana, M. Berggrenb, U. Mayb, T. Pisacanec, A. K. Granmob, and D. R. Adamsd. 2003. The Development of a Marine Natural Product-based Antifouling Paint. Biofouling, 2003. 19:197-205.

[3] Velayutham S, Sivaprakasam RM, Williams SF, Samuthirapandian R. Potential activity of in vitro antioxidant on methanolic extract of Babylonia zeylanica (bruguiere, 1789) from mudasalodai, southeast coast of india. Int J Pharm Pharm Sci Res 2014; 4(3): 60-4.

[4] Giftson, hermina and jamila Patternson. 2016. Evaluation of Antibacterial Activity of crude Extracts of gastropod, 
Harpa davidis, Roding 1798, from Kanyakumari Coast against isolated Human and Fish Pathogens. Asian Journal of Pharmaceutical and Clinical Research. Vol. 9.

[5] Nimah, Shofiatun., Widodo Farid Ma'ruf dan Agus Trianto. 2012. Bioactivity Test of Extract Sand Sea Cucumber (Holothuria scabra) Against Pseudomonas aeruginosa and Bacillus cereus. Journal of Fisheries. Vol. 1. Page: 1.

[6] Onibala, Hens. 2013. Identification of Bacillus sp. on Some Points of Frozen Tasteless Smoked Tuna Process. Journal of Fisheries and Thropical Marine. Vol. 9.

[7] Radjasa O.K., Wiese, J., Sabdono, A., \& Imhoff, J. F. 2008.Corals as source of bacteria with antimicrobial activity. Journal of Coastal Development, 11(3):121-130.

[8] Lay, BW. 1994. Microbia Analysis in Laboratory. Jakarta (ID): PT. Raja Grafindo Persada.

[9] Holt., J.G., N.R. Kreig., P.H.A. Sneath., J.T. Staley and S.T. Williams. 1974. Bergey's Manual of Determinative Microbiology. 9th ed. The Williams and Wilkins Co, Baltimore.

[10] Hadioetomo, R.S. 1993. Fundamental of Microbiology in Technical Practice and Laboratory Procedural. Jakarta: Gramedia.

[11] Gandjar, I., Koentjoro, I.R., Mangunwardoyo, W. Dan Soebagya, L. 1992. Practical Procedure for Microbiology.Jakarta: Department of Biology.

[12] Cowan and Steel's. 1993. Manual for The Identification of Medical Bacteria 3th ed., Cambridge University Press. England.
[13] Dharma, B. 1998. Indonesian Snail and Shells I \& II cet:2. PT Sarana Graha.Jakarta.Indonesia.

[14] Wahyuni, Sri., Arief Anthonius Purnama and Nurul Afifah. 2016. Molluscs Species Jenis-Jenis Moluska (Gastropoda and Bivalvia) in Mangrove Ecosystem at Dedap, Tasikputripuyu, District Kepulauan Meranti, Riau. Faculty of Teacher and Education Secience. Pasir Pengaraian University

[15] Silaen, Inchan Faolo., Boedi Hendrarto and Mustofa Niti Supardjo. 2013. Distribution and Abundance of Gatropods in Mangrove Forest Teluk Awur Jepara. Journal of Management of Aquatic Resources.Vol. 2 No. 3. Page : 93-103.

[16] Arbi, U.Y. 2014. Taxonomy and Phylogenic of Snail Potamididae (Gastropoda: Mollusca) in Indonesia Based on Morphology Character. Thesis. Pascasarjana Institute of Farming Bogor. Bogor.

[17] Sarah Saleh Abdu-Ilah Al-Saif., nevein Abdel-Raouf., hend A. El-Wazanani and Ibrahim A. Aref. 2013. Antibacterial Substances from Marine Algae isolated from jeddah Coast of Red Sea, Saudi Arabia. Saudi Journal of Biological Science.

[18] Nikham dan Taty E.B. 2012. Antibacteria Default Test of Mahkota Dewa (Phaleria Macrocarpa (Scheff) Boerl) from Gamma Radiation and Antibiotic Against Pathogenic Bacteria. Prosiding of Science and Technology. Serpong, pp. 168-174.

[19] Pelczar, M. J. dan Chan E.C.S. 2005. Microbiology Fundamental 2. UI-Press, Jakarta.

[20] Fauzi, A.S., Kasper, D.L., Longo, D.L, Braunwald, E., Hauser S,L., Jameson, J.L., dan Loscalzo, Joseph. 2008. Harrison's Principles of Internal.

[21] Hoerr, Verena., Gavin E. Duggan, Lori Zbytnuik., Karen K. H Poon., christina 
Große., Ute Neugebauer., Karen Methling, Bettina Loffler., and hans J. Vogel. 2016. Characterization and Prediction of The Mechanism of Action of Antibiotics Through NMR Metabolomics. BMC Microbiology.

[22] Davis, W.W., Stout, T.R. 1971. Disc Plate Method of Microbiological Assay. Journal of Microbiology. 22(4): 659665.

[23] Harrow, G.I., and R.K.A. Feltham. 2003. Cowan and Steel's Manual for The Identification of Medical Bacteria. 3th ed. Cambridge University Press, United Kingdom, 331p.
[24] Madigan, T. Madigan Bender KS, Buckley DH, Stahl DA. 2015. Brock Biology of Microorgnisms 14th edition. New Jersey (US): Pearson Prentice Hall.

[25] Ruyitno. 2004. Marine Bacteria and Its Role to Support Human Activity. Indonesian Institute of Science. Jakarta, 30 pages.

[26] Suryani, Titik and Farida Hikmawati. 2016. Quality and Storability of Green Mussels in Variation of Preservetive Type and Soaking Time. Muhammadiyah Surakarta University. 